\title{
Regulation of PACAP receptors in respiratory distress syndrome (RDS) of preterms and newborns
}

MJ Müller,, Aff1

Corresponding Affiliation: Aff1

A Kislat, $\stackrel{\text { Aff2 }}{ }$

A Hippe,, Aff2

A Poppe,

S Goldmann, Aff1

T Paul,,$\stackrel{\text { Affl }}{=}$

S Seeliger,, Aff1 Aff3

\begin{tabular}{|c|c|c|}
\hline \multicolumn{3}{|r|}{ ArticleInfo } \\
\hline ArticleID & $:$ & 59 \\
\hline ArticleDOI & $:$ & |10.1186/2194-7791-2-S1-A19 \\
\hline ArticleCitationID & $:$ & A19 \\
\hline ArticleSequenceNumber & $:$ & 19 \\
\hline ArticleCategory & $:$ & Meeting abstract \\
\hline ArticleFirstPage & $:$ & 1 \\
\hline ArticleLastPage & $:$ & 2 \\
\hline ArticleHistory & $::$ & \begin{tabular}{|ll} 
RegistrationDate & $: 2015-7-1$ \\
OnlineDate & $: 2015-7-1$
\end{tabular} \\
\hline ArticleCopyright & $|:|$ & $\begin{array}{l}\text { Müller et al.2015 } \\
\text { This article is published under license to BioMed Central } \\
\text { Ltd. This is an Open Access article distributed under the } \\
\text { terms of the Creative Commons Attribution License } \\
\text { (http://creativecommons.org/licenses/by/4.0), which permits } \\
\text { unrestricted use, distribution, and reproduction in any } \\
\text { medium, provided the original work is properly cited. }\end{array}$ \\
\hline
\end{tabular}

Aff1

Department of Pediatric Cardiology, Intensive Care Medicine and Neonatology, Georg August University Medical Center, D-37075 Göttingen, Germany

Aff2

Department of Dermatology, Heinrich Heine University, D-40225 Düsseldorf, Germany 
Abstracts of the 51st Workshop for Pediatric Research

51st Workshop for Pediatric Research

Göttingen, Germany

16-17 April 2015

This supplement has not been sponsored.

Meeting abstracts

\section{Background}

Prevalence of respiratory distress syndrome (RDS) caused by primary surfactant deficiency reaches $50 \%$ in infants below 32 weeks of gestational age. Increased alveolar surface tension leads to atelectatic and/or dystelectatic lung areas followed by inflammation resulting in development of a bronchopulmonary dysplasia (BPD) in $8 \%$ of these children. Standard RDS treatment consists of administration of exogenous surfactant. With the introduction of less invasive application (LISA) of exogenous surfactant, the use of Surfactant has significantly increased. Pituitary adenylate cyclase-activating polypeptide (PACAP) and its receptors (VPAC1, VPAC2, PAC1) trigger inflammatory reactions as well as anti-inflammatory processes.

\section{Materials and methods}

Using cell cultures, FACS and ELISA methods we analyzed surfactant effects on inflammation and PACAP-regulation and of its receptors in vivo and ex vivo.

\section{Results}

We were able to show that lipopolysaccharide (LPS) in prestimulated cells (PBMC) after surfactant treatment resulted in a significant up-regulation of pro-inflammatory interleukin (IL)-8. In tracheal secretory cells of surfactant-treated neonates we found an up-regulation of pro-inflammatory receptor VPAC1. Furthermore, in cell cultures we identified changes in the proliferation rates. Amniotic infection syndrome (AIS) is one of the major causes for premature birth resulting in RDS requiring exogenous surfactant. After pre-stimulation of PBMCs and subsequent addition of surfactant, pro-inflammatory signals were fortified. These results were confirmed by analysis of tracheal secretions of preterms and newborns.

\section{Conclusions}

Current findings may imply that safety and efficacy of routine surfactant administration should be reassessed as surfactant potentially triggers pulmonary inflammation and thus may contribute to BPD development. 